Bull. Chem. Soc. Ethiop. 2012, 26(3), 437-447.

ISSN 1011-3924

Printed in Ethiopia

DOI: http://dx.doi.org/10.4314/bcse.v26i3.13

(C) 2012 Chemical Society of Ethiopia

\title{
THEORETICAL STUDY OF CATALYTIC HYDROGENATION OF OXIRANE AND ITS METHYL DERIVATIVE
}

\author{
U.A. Kuevi, Y.G.S. Atohoun and J.B. Mensah" \\ Laboratoire de Chimie Théorique et de Spectroscopie Moléculaire (LACTHESMO), \\ Université d'Abomey-Calavi, 03 BP 3409 Cotonou, Bénin
}

(Received December 24, 2010; revised July 23, 2012)

\begin{abstract}
Oxirane $\left(\mathrm{C}_{2} \mathrm{H}_{4} \mathrm{O}\right)$ is an unsaturated heterocyclic compound and methyloxirane $\left(\mathrm{C}_{3} \mathrm{H}_{6} \mathrm{O}\right)$ is its methyl derivative. Theoretical studies on catalytic hydrogenation of both compounds, in presence of aluminium chloride $\left(\mathrm{AlCl}_{3}\right)$ catalyst, are carried out. The products of reactions are ethanol and propan-1-ol from oxirane and methyloxirane, respectively. According to the variations of chemical parameters throughout the processes, the mechanisms of both reactions have been proposed.
\end{abstract}

KEY WORDS: Hydrogenation, Oxirane, Methyloxirane, Aluminium chloride, Propan-1-ol, Ethanol, HF, MP2, DFT, B3LYP, lanl2dz basis set

\section{INTRODUCTION}

Catalytic hydrotreating process is a technique of purification of the crude oil with the aim of the improvement of the quality and the stability of fuels and lubricants. This is performed by the destruction of heterocyclic compounds and by the saturation of unsaturated hydrocarbons under the effect of the hydrogen pressure in presence of catalyst and at high temperature $[1,2]$. Several teams of researchers in chemistry are applying themselves throughout the world to resolve this important economic problem which also touches to the health of people. The aim of work is to provide to the industrialists, efficient catalysts and of best quality. Among hydrotreating catalysts there are catalysts based on aluminium such as Al-Co-Mo, Al-Ni-Mo, $\mathrm{Pd} / \mathrm{Al}_{2} \mathrm{O}_{3}, \mathrm{PdS} / \mathrm{Al}_{2} \mathrm{O}_{3}$ [3-8]. In the present work, the catalyst used is the aluminium chloride $\left(\mathrm{AlCl}_{3}\right)$. It is a Lewis acid able to form complex compounds with oxirane or methyloxirane molecules which contain free electronic pairs. The modelling of hydrogenation process has been carried out in order to determine the mechanism of hydrogenation of oxirane and its methyl derivative. The simulations of the hydrogenation of oxirane and methyloxirane without catalyst have been performed in a preliminary work, but they were not successful. That is the reason which led to the need to consider the use of a catalyst for the hydrogenation of these molecules.

\section{METHODOLOGY}

\section{Calculation methods and programs}

The calculation methods used in the present work were HF, MP2 and DFT with B3LYP functional in the lanl2dz basis set, using program Gaussian 98W program [9-15]. The transition states were found using QST3 method. The drawings of chemical systems were produced with ChemDraw or GaussView 3.09 and the curves of variation of interatomic distances, the curves of variation of Mulliken atomic charges and the energy diagrams of system were plotted with Microsoft Office Excel 2007.

The present work was carried out in the Laboratoire de Chimie Théorique et de Spectroscopie Moléculaire (LACTHESMO) of Abomey-Calavi University in Benin Republic.

${ }^{*}$ Corresponding author. E-mail: menfolben@yahoo.fr 


\section{Modelling of reaction}

Two steps characterized each of the two reactions: (i) adsorption of reactant on catalyst and (ii) reaction of hydrogen molecule with the complex (catalyst-reactant) formed at the adsorption.

The process simulation consists to approach the reactant to the catalyst until the adsorption, and then to approach the hydrogen molecule to the complex formed until the optimization of all the system. The structures of molecules contained in the chemical systems studied are represented (Figure 1).

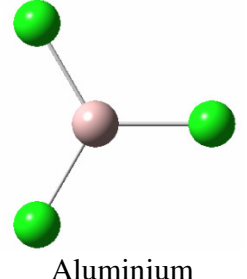
chloride $\left(\mathrm{AlCl}_{3}\right)$

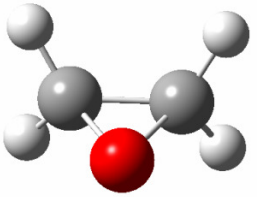

Oxirane

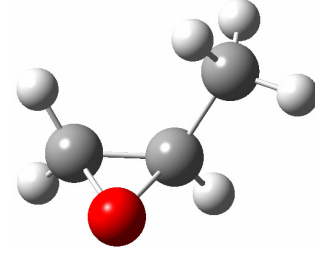

Methyloxirane $\left(\mathrm{C}_{3} \mathrm{H}_{6} \mathrm{O}\right)$

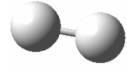

Hydrogen

$\left(\mathrm{H}_{2}\right)$

Figure 1. Drawings of molecules contained in the chemical systems studied.

During the hydrogenation process of each molecule, one atom of the hydrogen molecule is turned to the oxygen atom $\mathrm{O}$ of the adsorbed molecule. At the beginning of process, the distance of $\mathrm{OH}$ between those both atoms was $10 \AA$. Then, the second atom of hydrogen molecule will be almost at the same distance to the two carbon atoms involved in the cycle of the molecule (10.05 $\AA$ on the average). During the process, this second atom of the hydrogen molecule was free for taking the most suitable position on one or the other of two carbon atoms involved in the cycle of each of the two molecules.

\section{RESULTS AND DISCUSSION}

\section{Molecule of oxirane}

During the adsorption stage, $\mathrm{Al}^{8} \mathrm{O}^{1}$ is the geometric parameter of system for which the variation is kept under control until the relaxation of the whole of system at the end of process. This distance is progressively decreased from $10 \AA$ and in the optimized adsorptive geometry, it was $1.859 \AA$. The HF adsorption energy was equal to -0.0783 Hartree (or $-197.82 \mathrm{~kJ}$ ). The obtained complex structure is represented on the Figure 2.

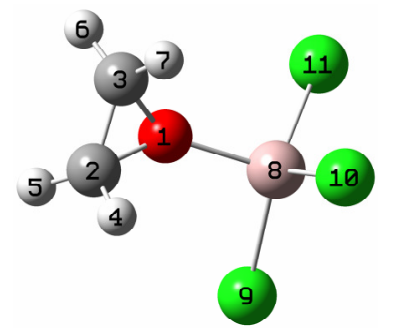

Figure 2. Structure of the obtained complex from the oxirane adsorption on $\mathrm{AlCl}_{3}$. 
During the hydrogenation stage, the geometric parameter for which the variation is kept under control is the interatomic distance $\mathrm{O}^{1} \mathrm{H}^{12}$ which was decreased from $10 \AA$ until to obtain the best stability of all system. Other geometric parameters have varied too. Figure 3 shows the energies of system, computed by HF method, at the main stages of the reaction.

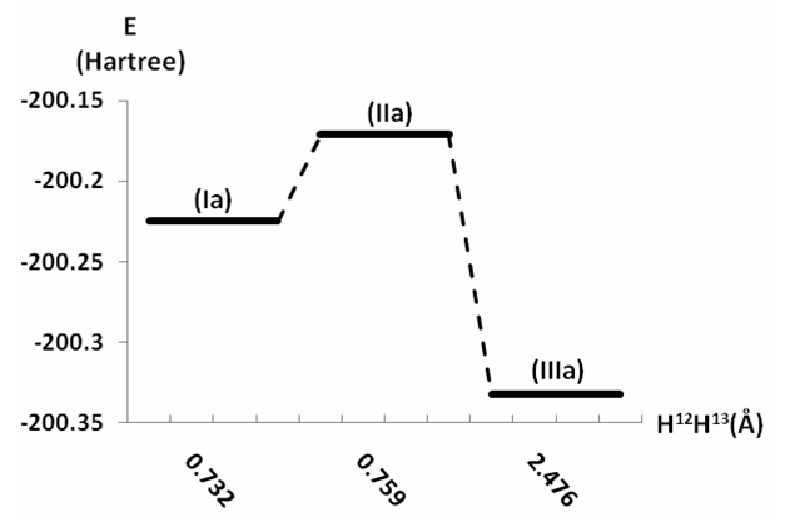

Figure 3. Energies of system at the main stages of oxirane hydrogenation in presence of $\mathrm{AlCl}_{3}$ : beginning of reaction $\left(\mathrm{E}_{\mathrm{Ia}}=-200.225\right.$ Hartrees $)$, transition state $\left(\mathrm{E}_{\mathrm{IIa}}=-200.171\right.$ Hartrees) and end of reaction ( $\mathrm{E}_{\mathrm{III}}=-200.332$ Hartrees).

The energetic study of the reaction allowed to find the activation energy (0.054 Hartree or $136.427 \mathrm{~kJ})$ and reaction energy $(-0.107$ Hartree or $-270.34 \mathrm{~kJ})$. This negative value of reaction energy indicates that the reaction is exoenergetic.

Figures 4 and 5 show respectively the variations of some interatomic distances, calculated by HF method, and those of Mulliken atomic charges during the hydrogenation process.

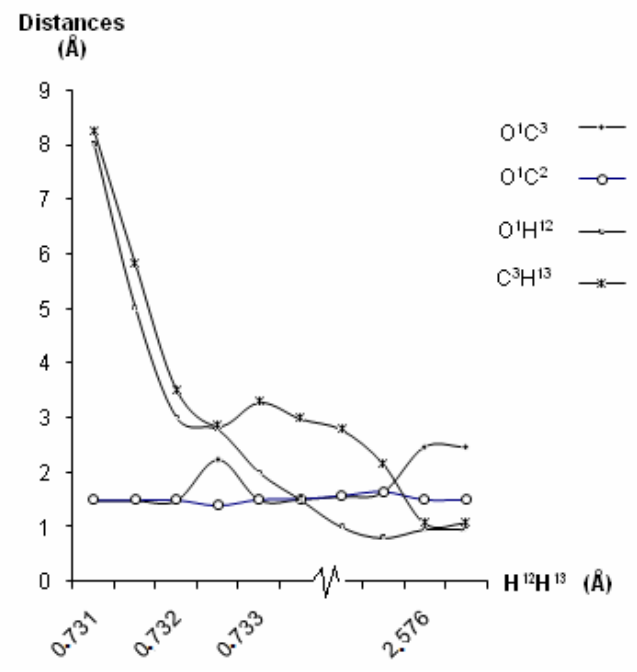

Figure 4. Variation of HF interatomic distances during the catalytic hydrogenation of the oxirane in presence of $\mathrm{AlCl}_{3}$.

Bull. Chem. Soc. Ethiop. 2012, 26(3) 


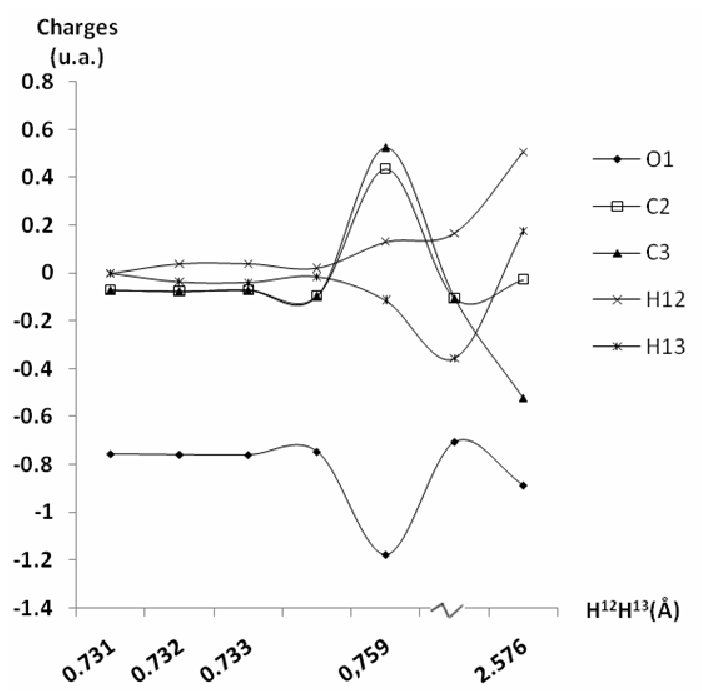

Figure 5. Variation of HF Mulliken atomic charges during the catalytic hydrogenation of the oxirane in the presence of $\mathrm{AlCl}_{3}$.

During the process, $\mathrm{H}^{12} \mathrm{H}^{13}$ distance remained practically constant until the $\mathrm{O}^{1} \mathrm{H}^{12}$ distance became $1.500 \AA$. At the end of process, $\mathrm{H}^{12} \mathrm{H}^{13}$ reached $2.589 \AA$, while $\mathrm{O}^{1} \mathrm{H}^{12}$ and $\mathrm{C}^{3} \mathrm{H}^{13}$ became $0.953 \AA$ and $1.084 \AA$, respectively. These bond lengths prove that the bond $\mathrm{H}^{12} \mathrm{H}^{13}$ is broken while $\mathrm{C}^{3} \mathrm{H}^{13}$ and $\mathrm{O}^{1} \mathrm{H}^{12}$ bonds are established, respectively. In addition, the distance $\mathrm{O}^{1} \mathrm{C}^{3}$ is considerably increased to reach $2.469 \AA$ at the end. This result indicates the rupture of this bond. The distances $\mathrm{O}^{1} \mathrm{C}^{2}$ and $\mathrm{C}^{2} \mathrm{C}^{3}$ practically remained constant during the process; this proves that the concerned bonds did not vary.

On the basis of these observations, we see that the reaction between a hydrogen molecule and an oxirane molecule is a reaction of addition which ends in the opening of the cycle with formation of an ethanol molecule. However, we proceeded to a comparison of the geometrical parameters of the obtained compound to those of the ethanol molecule (Table 1).

Table 1. Computed geometrical parameters of the reaction product and of ethanol molecule.

\begin{tabular}{|l|c|c|c|}
\hline Parameters $(\mathrm{HF})$ & Reaction product & Ethanol & Gap \\
\hline Distances $(\AA)$ & 0.953 & 0.953 & 0.000 \\
\hline $\mathrm{O}^{1} \mathrm{H}^{12}$ & 1.443 & 1.444 & -0.001 \\
\hline $\mathrm{O}^{1} \mathrm{C}^{2}$ & 1.529 & 1.521 & 0.008 \\
\hline $\mathrm{C}^{2} \mathrm{C}^{3}$ & 1.084 & 1.083 & 0.001 \\
\hline $\mathrm{C}^{3} \mathrm{H}^{13}$ & 112.21 & 107.35 & 4.86 \\
\hline Angles $\left(^{\circ}\right)$ & 113.60 & 114.05 & -0.45 \\
\hline $\mathrm{O}^{1} \mathrm{C}^{2} \mathrm{C}^{3}$ & 111.25 & 110.24 & 1.01 \\
\hline $\mathrm{H}^{12} \mathrm{C}^{1} \mathrm{C}^{2}$ & -154.0442 & -154.0444 & 0.0002 \\
\hline $\mathrm{C}^{2} \mathrm{C}^{3} \mathrm{H}^{13}$ & & & \\
\hline Energy (Hartree) &
\end{tabular}

The largest difference is observed for the angle $\mathrm{O}^{1} \mathrm{C}^{2} \mathrm{C}^{3}$ (approximately 4.5\%). In addition, these values are close to those recorded in the software "Cambridge Crystallographic Data Center" (CCDC) $[15,16]$. 
We were also interested in the determination of the mechanism of the various transformations intervened during the process. For this, we performed the analysis of Mulliken atomic charges of $\mathrm{H}^{12}, \mathrm{H}^{13}, \mathrm{C}^{2}, \mathrm{C}^{3}$ and $\mathrm{O}^{1}$ atoms from the beginning at the transition state of reaction. The variations of charges have shown that from beginning to the transition state: (i) the hydrogen atom $\mathrm{H}^{12}$ of the hydrogen molecule became poorer of electronic charge and the atom $\mathrm{H}^{13}$ gained it. Then the charge carried by $\mathrm{H}^{12}$ is positive and that carried by $\mathrm{H}^{13}$ is negative (Figure 5). This translates a heterolytic rupture of the bond $\mathrm{H}-\mathrm{H}$ in the hydrogen molecule, and (ii) Simultaneously, the carbon atom $\mathrm{C}^{3}$ became poorer of electronic charge and the oxygen atom $\mathrm{O}^{1}$ gained it. Then the charge carried by $\mathrm{C}^{3}$ is positive and that carried by $\mathrm{O}^{1}$ is negative (Figure 5). This translates a heterolytic rupture of the bond $\mathrm{O}^{1} \mathrm{C}^{3}$ of oxirane molecule.

Indeed, the electronic doublet forming the bond $\mathrm{O}^{1} \mathrm{C}^{3}$ appreciably moved towards the oxygen atom $\mathrm{O}^{1}$. Simultaneously, the atom of hydrogen $\mathrm{H}^{13}$ with its negative charge underwent an attraction towards the carbon atom $\mathrm{C}^{3}$ which carried at this stage of the process a positive charge.

Figure 6 shows the drawings of the system structure at the main stages of the process. The transition state is characterised by a vibration with a negative frequency $\left(-381.55 \mathrm{~cm}^{-1}\right)$ whose the intensity is quite important $(117.997 \mathrm{~km} /$ mole $)$. The geometric parameters of this transition state were $1.738,2.172$ and $0.759 \AA$ for $\mathrm{C}^{3} \mathrm{H}^{13}, \mathrm{O}^{1} \mathrm{H}^{12}$ and $\mathrm{H}^{12} \mathrm{H}^{13}$ bonds lengths, respectively.

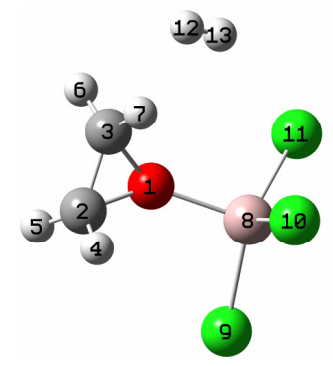

(a) Beginning of reaction (Ia)

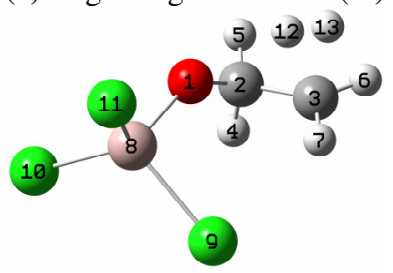

(b) Transition state (IIa)

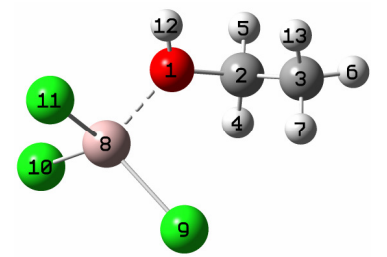

(c) End of reaction (IIIa)

Figure 6. Drawings of the system structure at the main stages of the hydrogenation of oxirane in the presence of $\mathrm{AlCl}_{3}$. 
On the basis of these results, a probable mechanism of the oxirane hydrogenation in the presence of the aluminium chloride was proposed (Figure 7). The opening of oxirane ring is occurred in accordance with the literature data [17-20].

Oxirane $+\mathrm{H}_{2} \stackrel{\mathrm{AlCl}_{3}}{\longrightarrow}$ Ethanol

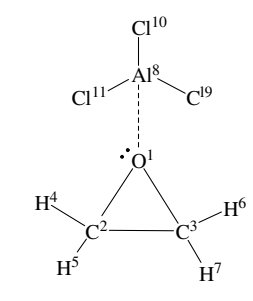

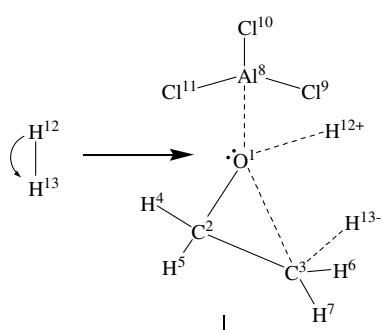

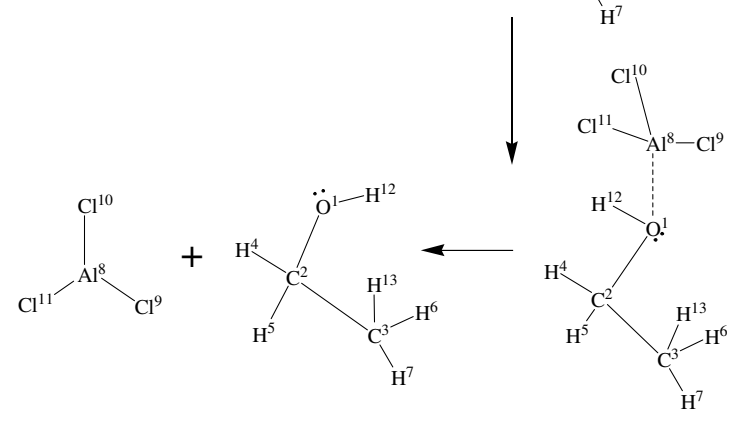

(a)

(b)

Figure 7. Reaction scheme (a) and probable mechanism of oxirane hydrogenation in the presence of $\mathrm{AlCl}_{3}(\mathrm{~b})$.

\section{Molecule of methyloxirane}

The reaction coordinates handled during the simulation of various stages of process are the distance $\mathrm{Al}^{11} \mathrm{O}^{1}$ during the adsorption and $\mathrm{O}^{1} \mathrm{H}^{15}$ distance during the hydrogenation. During the adsorption stage the $\mathrm{Al}^{11} \mathrm{O}^{1}$ distance varied from 10.00 to $1.8474 \AA$. The adsorption energy computed by HF method is -0.083 Hartree (or $-208.94 \mathrm{~kJ}$ ). Figure 8 shows the drawing of structure of obtained complex at the adsorption.

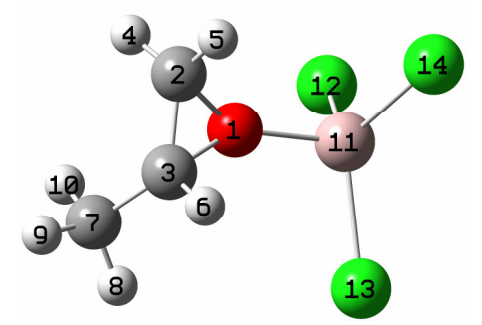

Figure 8. Structure of the obtained complex from the methyloxirane adsorption on $\mathrm{AlCl}_{3}$.

Bull. Chem. Soc. Ethiop. 2012, 26(3) 
Figure 9 shows the energies of system, computed by HF method, at the main stages of the methyloxirane hydrogenation in presence of $\mathrm{AlCl}_{3}$.

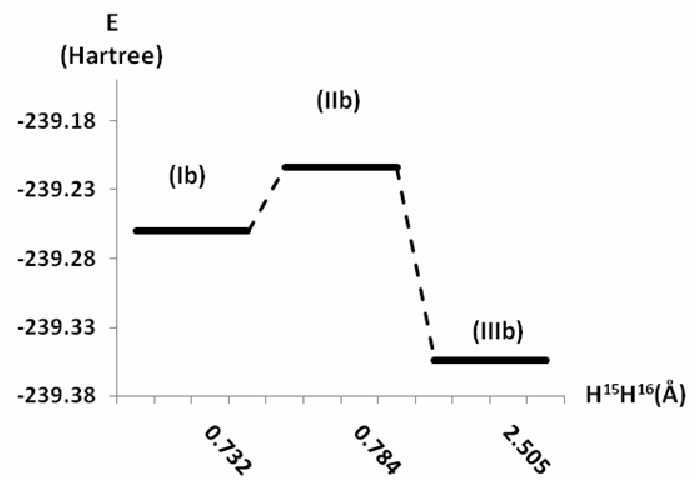

Figure 9. Energies of system at the main stages of methyloxirane hydrogenation in presence of $\mathrm{AlCl}_{3}$ : beginning of reaction $\left(\mathrm{E}_{\mathrm{Ib}}=-239.260\right.$ Hartrees $)$; transition state $\left(\mathrm{E}_{\mathrm{IIb}}=-239.214\right.$ Hartrees) and end of reaction $\left(\mathrm{E}_{\mathrm{IIIb}}=-239.354\right.$ Hartrees $)$.

The thermodynamic and kinetic data provided by the energetic study of the reaction are the activation energy $(0.046$ Hartree or $116.216 \mathrm{~kJ})$ and the reaction energy (-0.094 Hartree or $237.485 \mathrm{~kJ})$. Like in the first case this last reaction is also exoenergetic.

The variations of interatomic distances and Mulliken atomic charges of system atoms during the catalytic hydrogenation of the methyloxirane in presence of $\mathrm{AlCl}_{3}$ are shown in Figures 10 and 11 , respectively.

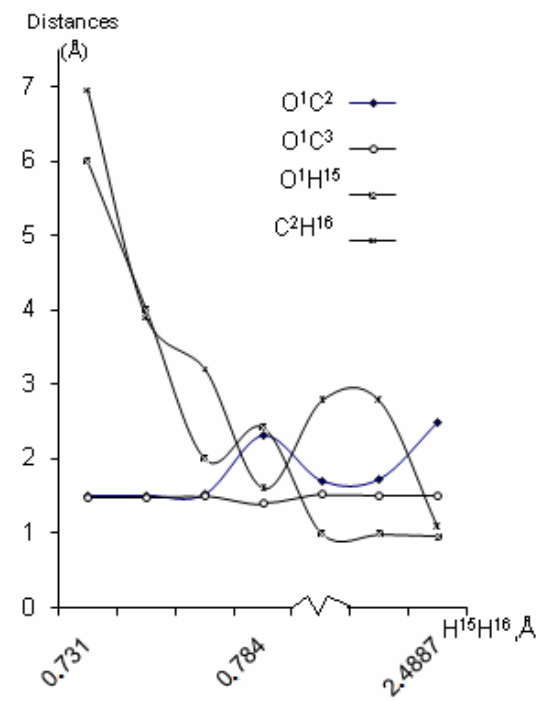

Figure 10. Variation of HF interatomic distances during the catalytic hydrogenation of the methyloxirane in presence of $\mathrm{AlCl}_{3}$.

Bull. Chem. Soc. Ethiop. 2012, 26(3) 


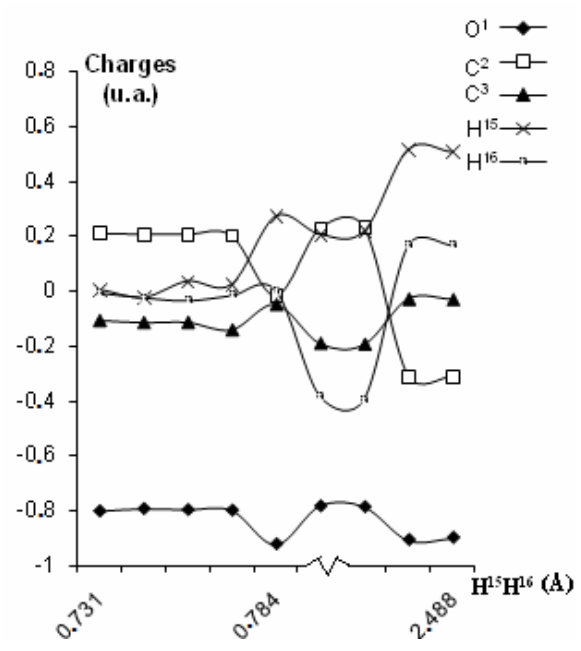

Figure 11. Variation of HF Mulliken charges on the atoms during the catalytic hydrogenation of the methyloxirane in the presence of $\mathrm{AlCl}_{3}$.

During the hydrogenation process, the distance $\mathrm{H}^{15} \mathrm{H}^{16}$ remained practically constant until the distance $1.500 \AA$ of the reaction coordinates $\left(\mathrm{O}^{1} \mathrm{H}^{15}\right)$. Then it reached $1.064 \AA$ when the length $\mathrm{O}^{1} \mathrm{H}^{15}$ became $1.000 \AA$. This last length of $\mathrm{H}^{15} \mathrm{H}^{16}$ proves that in the hydrogen molecule, the $\mathrm{H}-\mathrm{H}$ bond is broken. At this step of the reaction, we noted a sensitive stretching of the $\mathrm{O}^{1} \mathrm{C}^{2}$ bond, which can be the prelude to the rupture of this bond. From beginning to the same value of the $\mathrm{O}^{1} \mathrm{H}^{15}$ distance $(1 \AA)$, we also observe a decrease of the distance $\mathrm{C}^{2} \mathrm{H}^{16}$, on the other hand (Figure 10). At the process end, when the system is completely relaxed, the values of these geometric parameters showed that there have been ruptures of old bonds and formations of new bonds.

Indeed, the $\mathrm{O}^{1} \mathrm{C}^{2}$ bond of methyloxirane molecule and $\mathrm{H}^{15} \mathrm{H}^{16}$ bond of hydrogen molecule were broken and the values of their lengths became respectively 2.476 and $2.489 \AA$ at the reaction end. Simultaneously, the $\mathrm{O}^{1} \mathrm{H}^{15}$ and $\mathrm{C}^{2} \mathrm{H}^{16}$ bonds were formed and their lengths were 0.953 and $1.088 \AA$ A , respectively.

To confirm these results we have compared the geometrical parameters of the reaction product to those of propan-1-ol (Table 2).

Table 2. Computed geometrical parameters of the reaction product and of propan-1-ol molecule.

\begin{tabular}{|l|c|l|l|}
\hline Parameters $(\mathrm{HF})$ & Reaction product & Propan-1-ol & Gap \\
\hline Distances $(\AA)$ & & & \\
\hline $\mathrm{O}^{1} \mathrm{H}^{15}$ & 0.953 & 0.953 & 0.000 \\
\hline $\mathrm{O}^{1} \mathrm{C}^{2}$ & 2.476 & 2.471 & 0.005 \\
\hline $\mathrm{O}^{1} \mathrm{C}^{3}$ & 1.444 & 1.442 & 0.002 \\
\hline $\mathrm{C}^{2} \mathrm{C}^{3}$ & 1.532 & 1.530 & 0.002 \\
\hline $\mathrm{C}^{2} \mathrm{C}^{7}$ & 1.536 & 1.537 & 0.001 \\
\hline $\mathrm{C}^{2} \mathrm{H}^{16}$ & 1.088 & 1.084 & 0.004 \\
\hline Angles $\left(^{\circ}\right)$ & & & \\
\hline $\mathrm{O}^{1} \mathrm{C}^{3} \mathrm{C}^{2}$ & 112.62 & 112.43 & 0.19 \\
\hline $\mathrm{H}^{15} \mathrm{O}^{1} \mathrm{C}^{3}$ & 113.49 & 113.61 & -0.12 \\
\hline $\mathrm{C}^{3} \mathrm{C}^{2} \mathrm{H}^{16}$ & 109.27 & 108.62 & 0.65 \\
\hline Energy (Hartree) & -193.0664 & -193.0668 & 0.0004 \\
\hline
\end{tabular}

Bull. Chem. Soc. Ethiop. 2012, 26(3) 
The results of the Table 2 show that the parameters of the reaction product are very close to those of propan-1-ol. The small differences observed are probably the fact of interactions of the catalyst on the reaction product at the process end. In addition, these values are also close to those recorded in the software "Cambridge Crystallographic Data Center" (CCDC) [15, 21].

The study of the variations of Mulliken atomic charges carried by atoms $\mathrm{H}^{15}, \mathrm{H}^{16}, \mathrm{C}^{2}, \mathrm{C}^{3}$ and $\mathrm{O}^{1}$ showed that: (i) the hydrogen atom $\mathrm{H}^{15}$ of the hydrogen molecule became poorer of electronic charge and the atom $\mathrm{H}^{16}$ gained it. Then the charge carried by $\mathrm{H}^{15}$ is positive and that carried by $\mathrm{H}^{16}$ is negative (Figure 11). Then the rupture of the bond $\mathrm{H}-\mathrm{H}$ in the hydrogen molecule is heterolytic and (ii) also, the carbon atom $\mathrm{C}^{2}$ became poorer of electronic charge and the oxygen atom $\mathrm{O}^{1}$ gained it. Then the charge carried by $\mathrm{C}^{2}$ is positive and that carried by $\mathrm{O}^{1}$ is negative (Figure 11). The rupture of the bond $\mathrm{O}^{1} \mathrm{C}^{2}$ of methyloxirane molecule is heterolytic.

On the basis of this study, it appeared that, by electrostatic actions, the hydrogen atoms $\mathrm{H}^{15}$ and $\mathrm{H}^{16}$ have been attracted respectively by $\mathrm{O}^{1}$ and $\mathrm{C}^{2}$. New bonds are formed between $\mathrm{O}^{1}$ and $\mathrm{H}^{15}$, on one hand, and between $\mathrm{C}^{2}$ and $\mathrm{H}^{16}$, on the other hand. Thus, the reaction between a hydrogen molecule and a methyloxirane molecule is an addition reaction which preferentially led to the formation of the linear molecule of propan-1-ol. This occurs because the methyl group carried by a carbon atom $\mathrm{C}^{2}$ of the methyloxirane molecule allows the formation of the most stable carbocation (secondary) after the heterolytic rupture of the $\mathrm{C}^{2} \mathrm{O}^{1}$ bond.

Figure 12 shows the drawings of the system structure at the main stages of the process. The transition state is characterised by a vibration with a negative frequency $\left(-598.0120 \mathrm{~cm}^{-1}\right)$ whose the intensity is important $(325.481 \mathrm{~km} / \mathrm{mole})$. The geometric parameters of this transition state were $1.603,1.796$ and $0.784 \AA$ for $\mathrm{C}^{2} \mathrm{H}^{16}, \mathrm{O}^{1} \mathrm{H}^{15}$ and $\mathrm{H}^{15} \mathrm{H}^{16}$ bonds lengths, respectively.

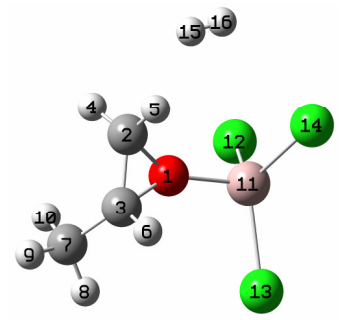

(a) Beginning of reaction (Ib)

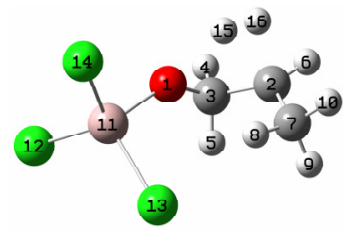

(b) Transition state (IIb)

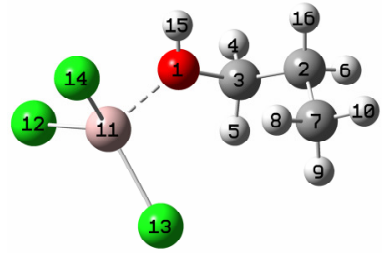

(c) End of reaction (IIIb)

Figure 12. Drawings of the system structure at the main stages of the hydrogenation of methyloxirane in the presence of $\mathrm{AlCl}_{3}$.

Bull. Chem. Soc. Ethiop. 2012, 26(3) 
On the basis of these results, a probable mechanism of the methyloxirane hydrogenation in the presence of the aluminium chloride is proposed (Figure 13). The opening of methyloxirane ring is occurred in accordance with the literature data [17-20,22].
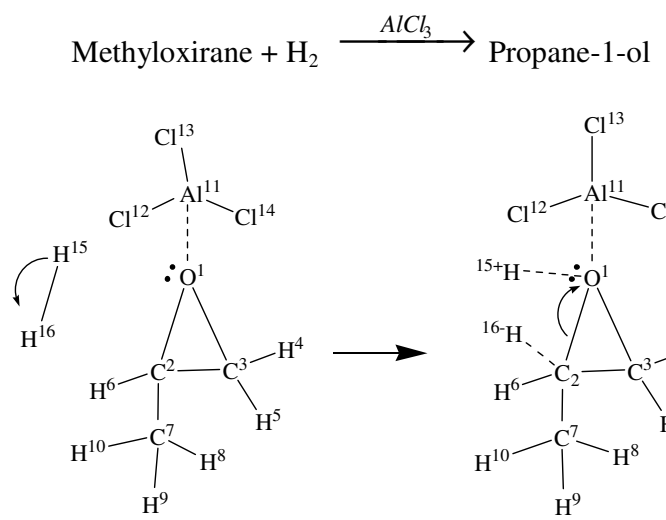

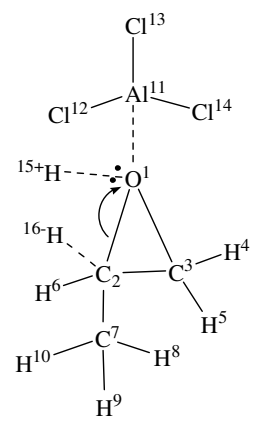

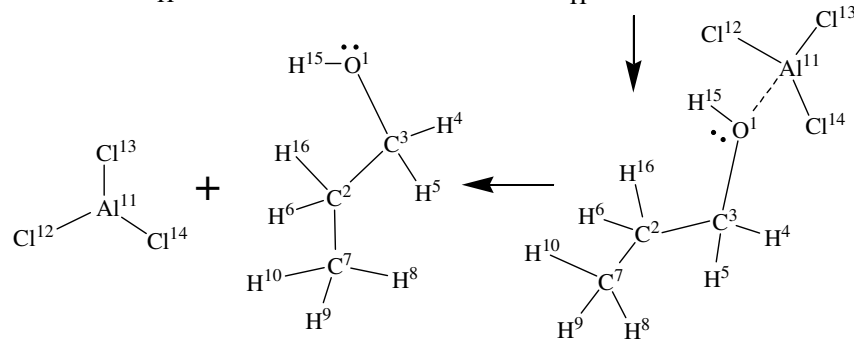

(b)

Figure 13. Reaction scheme (a) and probable mechanism of methyloxirane hydrogenation in the presence of $\mathrm{AlCl}_{3}(\mathrm{~b})$.

\section{CONCLUSIONS}

The study performed in this work permitted to do the following observations: (i) hydrogenation of both molecules (oxirane and methyloxirane) has need of a catalyst use, (ii) the hydrogenation of both molecules in the presence of aluminium chloride catalyst is possible and the products of reactions are ethanol and propan-1-ol respectively for the oxirane and the methyloxirane molecules, and (iii) the values of activation energies $(136.43 \mathrm{~kJ}$ and $116.22 \mathrm{~kJ}$ respectively for oxirane and methyloxirane) reveal that the hydrogenation of the methyloxirane is the most kinetically favored. Our next work will concern the same processes with a new approach which takes into account the effect of the solvent as well as those of the temperature and the pressure.

\section{REFERENCES}

1. Kraus, J.; Zdrazil, M. React. Kinet. Catal. Lett. 1977, 6, 475.

2. Hargreaves, A.E.; Rose, J.R.H. J. Catal. 1979, 56, 363.

3. Salmeron, M.; Somorjai, G.; Wold, A.; Chianelli, R.; Liang, K.S. Chem. Phys. Lett. 1982, 90, 105.

4. Tanaka, K.; Okuhara, T. J. Catal. 1982, 78, 155. 
5. Chianelli, R.R.; Tauster, S.J. J. Catal. 1981, 71, 228.

6. Chadwick, D.; Breysse, M. J. Catal. 1981, 71, 226.

7. Valyon, J.; Hall, W.K. J. Catal. 1983, 84, 216.

8. Mensah, J.B.; Kuevi, U.A.; Atohoun, Y.G.S. Theoretical Aspects of Catalysis, Vayssilov, G.; Mineva, T. (Ed.), Heron Press: Sofia; 2008; pp 29-44.

9. Rivail, J.L. Elements de Chimie Quantique à l'usage des Chimistes, 2nd ed., Editions du CNRS: Paris; 1994; p 400.

10. Melius, C.F.; Goddard, W.A. Phys. Rev. A 1974, 10, 1528.

11. Kahn, L.R.; Baybut, P.; Truhlatd, D.G. J. Chem. Phys. 1976, 65, 3826.

12. Becke, A.D. J. Chem. Phys. 1993, 98, 5648.

13. Lee, C.; Yang, W.; Parr, R.G. Phys. Rev. B 1980, 37, 785.

14. Frisch, M.J.; Trucks, G.W.; Schlegel, H.B.; Scuseria, G.E.; Robb, M.A.; Cheeseman, J.R.; Zakrzweski, V.G.; Montgomery, J.A.; Stratmann, R.E.; Burant, J.C.; Dapprich, S.; Millam, J.M.; Daniels, A.D.; Kudin, K.N.; Strain, M.C.; Farkas, O.; Tomasi, J.; Barone, V.; Cossi, M.; Cammi, R.; Mennucci, B.; Pomelli, C.; Adamo, C.; Clifford, S.; Ochterski, J.; Petersson, G.A.; Ayala, P.Y.; Cui, Q.; Morokuma, K.; Malick, D.K.; Rabuck, A.D.; Raghavachari, K.; Foresman, J.B.; Cioslowski, J.; Ortiz, J.V.; Stefanov, B.B.; Liu, G.; Liashenko, A.; Piskorz, P.; Komaromi, I.; Gomperts, R.; Martin, R.L.; Fox, D.J.; Keith, T.; Al-Laham, M.A.; Peng, C.Y.; Nanayakkara, A.; Gonzalez, C.; Challacombe, M.; Gill, P.M. W.; Johnson, B.G.; Chen, W.; Wong, M.W.; Andres, J.L.; Head-Gordon, M.; Replogle, E.S.; Pople, J.A. Gaussian 98 (Revision A.1), Gaussian Inc.: Pittsburgh PA; 1998.

15. KlarK, T. (Ed.) Kompioutrnaya Himiya (Computational Chemistry), Mir: Moscow; 1990; pp. 6, 10, 270.

16. Johnson, P.-G. Acta Crystallogr., Sect.B; Struct. Crystallogr, Cryst.Chem. 1975, 3, 232.

17. Chernishov, D.; Hostettler, M.; Tornroos, K.W.; Burgi, H.B. Angew. Chem., Int. Ed. 2003, $42,3825$.

18. Kato, K.; Sugohara, M.; Tohnai, N.; Sada, K.; Miyata, M. Eur. J. Org. Chem. 2004, 981. 19. Suitchmezian, V.; Jess, I.; Nather, C. Int. J. Pharm. 2006, 323, 101.

20. Lyle, R.E.; Krueger, W.E. J. Org. Chem. 1967, 32, 2873.

21. Odabasuglu, M.; Albayrak, C. Acta Crystallogr., Sect. E; Struct. Rep. Online 2004, 60, 142.

22. Palinko, I. J. mol. Cat. A 1999, 140, 196. 